DoI: http://dx.doi.org/10.11157/sites-vol12issiid272

- ARTICLE -

\title{
QUESTIONING THE ROLE OF 'FAITH' IN A MICROPOLITICS OF THE NEOLIBERAL UNIVERSITY
}

\author{
Edwin Ng
}

\begin{abstract}
This paper proposes that the question of the role of faith in academia invites collective attention because it pertains to a micropolitics of the neoliberal university. It locates the question of faith within discourses that foreground the academic's experience of the vicissitudes of the scholarly profession in order to expose and transform the depoliticising, injurious, and silencing effects of the neoliberal academic regime. The paper proposes that faith can play a role in revitalising the relational capacities that are presently inhibited by the prevailing climate of competitive individualism and precarity. Building on deconstructive writings on faith, the paper will develop this two-pronged proposition: that faith is necessary to foster intellectual hospitality, relations of reciprocity, and solidarity; and that we investigate it in relation to the immaterial labour of scholarly affect.
\end{abstract}

Keywords:

\section{INTRODUCTION}

The aim of this paper is to show that faith, or at least the question of the role of faith in academia, invites collective attention because it pertains to a micropolitics of the university. It first presents an overview of the challenges facing the university in order to locate the question of faith within micropolitical analyses that are seeking to expose and transform the depoliticising, injurious, and silencing effects of the neoliberal academic regime. In foregrounding the academic subject's experiences of the vicissitudes of the scholarly profession experiences that are typically effaced in scholarly exchange, despite widespread interest in reflexive scholarship - these micropolitical discourses can serve to foster collegiality, collective will, and solidarity. What I am proposing, in other words, is that faith can play a role in revitalising the relational capaci- 
ties that are inhibited within the prevailing climate of competitive individualism and precarity generated by technologies of audit, feedback, performance, and risk-management. I will develop this argument by considering how these enunciative practices of 'speaking personally' may perform a kind of countercultural 'truth-telling', before examining Derrida's understanding of faith to demonstrate how these modes of address are constituted by a testimonial relation. Inasmuch as they are making an appeal to the other, these micropolitical discourses must necessarily presuppose and perform such address in good faith. The paper will then consider how the question of faith might be located within current attempts to situate the role of scholarly affect in the struggle for a different university.

As this paper builds on existing debates about the ethico-political possibilities of 'speaking personally' in academic discourse, it would be helpful to begin by contextualising my personal and professional interest in faith. My ongoing research cross-fertilises my sacred and scholarly pursuits as a postcolonial 'Western Buddhist' convert (Ng 2012a, 2012b). I describe myself thus because even though I grew up in Singapore where Buddhism was a part of my diasporic 'Chinese' ancestral heritage, I only took an interest in Buddhist teachings when I migrated to Australia some 12 years ago for university studies and discovered Western translations of Buddhism. My research in academia (with a particular interest in cultural theory) is crucially informed by my interest in Buddhism. Over time it became clear that the question of faith and its role in this sacred-scholarly profession cannot be ignored - not least because it marks a point of tension between what is, on the one hand, the 'secular' commitment of the Western academy, and on the other, a 'religious' commitment involving a non-Western heritage that has been subject to the hegemonic imperatives of the former. The question of faith can therefore serve as a critical lens for interrogating the dynamics of knowledge-power relayed and contested through the university, academic work, and beyond in other (non-Western) heritages of understanding and popular cultural practices.

To sketch an outline of the question of faith I wish to develop, I would like to share an anecdote of a workshop I participated in, where, upon learning about my research interest a professor jokingly remarked, 'Perhaps there are some issues that you need to work on privately.' This remark drew laughter from the others present, and I felt compelled to join in. When the topic of my research interest arose on a separate occasion, the same professor said: 'You know, after all, Marx did say that religion is the opium of the masses.' Never mind that faith is irreducible to religion, or that this oft-quoted line by Marx has been grossly misconstrued: the metaphor of opium could be read in multiple ways 
and Marx's criticism of religion remains the subject of ongoing scholarly debate (McKinnon 2006; Roberts 2005). The message of this professor's remarks appears to be: matters of faith are not an appropriate subject for academic research, and since everyone knows that religion is a source of oppression, a serious scholar ought not be duped by such concerns. I share this anecdote to flag two key dimensions of my argument.

Firstly, the role of faith in a micropolitics of the neoliberal university can be explored in a general sense as a willingness to extend 'good faith' or intellectual hospitality towards the other of our discourses as well as those with whom we share a profession. Or to put it another way, we might think of the mode of address that is performed when we sign off letters with 'Yours faithfully'. With regard to the above encounters, I certainly do not wish to suggest that the professor harboured ill-will towards me (in fact, our interactions have been amicable). But in terms of its discursive effects, the sentiments expressed may function (even if unwittingly) to discourage intellectual hospitality and relations of reciprocity. Such a reactionary dismissal of subject matters that do not conform to conventional expectations about scholarly practice is arguably a manifestation of the normative power that is relayed through the imagined subjectivity' of the resolutely rational academic. Following Barbara Herrnstein Smith (1988) in conceiving of academia as a system of values, Matt Hills (2002: 3) has argued that 'academia ... is bounded by its own imagined subjectivity', which 'attributes valued traits of the subject "duly trained and informed" only to those within the given community, while denigrating or devaluing the "improper" subjectivity of those who are outside the community [or, those deemed to fall short of prevailing expectations]'. The resolutely rational academic is an imagined subjectivity 'because it does not relate to the actual subjectivities of embodied academics'. For when it comes down to it, there is no determinate way to adjudicate on the different approaches and truth claims within the academy on some objective ground of 'pure evidence.' Yet, 'the possibility that faith is the ultimate glue within academic argument is typically disavowed and ignored in favour of the imagined subjectivity of the rational academic' (Hills 2002: 3-4; emphasis added).

This paper's discussion of micropolitical analyses of the neoliberal university will show why it is important to interrogate the normative power of this imagined subjectivity - because in effacing the actual subjectivities of embodied academics, the imagined subjectivity of the resolutely rational and 'detached' academic may be mobilised to serve the hegemonic imperatives of the neoliberal university that function to inhibit the fostering of intellectual hospitality and sympathetic relations of reciprocity and solidarity. This point relates to 
the second dimension of my argument: that faith be investigated in relation to affect, and specifically for academia, in relation to what might be called 'scholarly affect' (Gregg 2006). As Hills notes, academia is never experienced purely as a pursuit of knowledge. It must necessarily solicit an affective response of conviction or trust that despite the incompleteness of understanding, our pursuit of knowledge can and will make a difference to the challenges facing the contemporary world. Perhaps, as Hills suggests with the metaphor of glue, we might say that academia must necessarily involve a faith-in-knowledge or faith-in-the-profession that holds us together in solidarity. This is the twopronged proposition I want to develop: that faith is necessary to foster intellectual hospitality, relations of reciprocity, and solidarity; and that we investigate it in relation to scholarly affect. I shall proceed by considering how critical discourses on the neoliberal university invite such an inquiry.

\section{A MICROPOLITICS OF THE NEOLIBERAL UNIVERSITY}

The following are some of the key problems generated by the corporate-driven neoliberal shift in the university. Decreasing allocation of state funding to higher education has led to declines in continuing or tenured appointments, heavy casualisation of the academic workforce, and a growing population of young people incurring student debts. Academia becomes increasingly governed by the norms of an audit culture and subject to managerial surveillance. Within this milieu, the value of research is measured according to the income it is able to secure for the university-as-corporation, and teaching is evaluated according to student retention numbers and 'client satisfaction'. Academia is managed increasingly in terms of disciplinary technologies like audit, feedback, performance, and risk management. Any notions of collegiality, collaboration, altruism, or activism are suppressed and suffocated in a climate of competitive individualism and the heavy air of precarity (Canaan and Shumar 2008; Hill and Kumar 2009).

As Rosalind Gill (2009) has mapped out, critical discourses on the neoliberal university have examined these problems in four overarching ways. Firstly, there is a critical or social theory approach that locates the transformation of academic work within accounts of late capitalism, network society, liquid modernity, knowledge society, or post-Fordism (Beck 2000; Bauman 2000; Sennett 2006; Hardt and Negri 2000). This set of discourses examines such issues as the blurring of boundaries between work and play; passionate attachment to work and the injunction to be an entrepreneurial creative labourer; and experiences of insecurity and anxiety about maintaining employment or meeting performance targets (Banks 2007; Gill and Pratt 2008; McRobbie 
2003; Ross 2003). Secondly, there is a broadly sociological approach that investigates the structural transformation of higher education by interrogating the implications of corporatisation (Evans 2005; Graham 2002; Washburn 2003). This set of discourses cautions against such trends as the instrumentalisation of education; the repositioning of students as 'customers' or 'clients' and lecturers as 'service-providers'; the poor working conditions for academics; and the systemic inhibition of organised resistance from trade unions and other grassroots organisations. Thirdly, there is a Foucauldian-inspired approach that problematises the governmentality of the neoliberal university and the apparatuses of control that target the academic subject. This set of discourses questions the will to knowledge-power of new and emerging forms of discipline and technologies of selfhood that normalise the self-monitoring, selfimproving 'responsible' and 'autonomous' subject required by the neoliberal university (Davies and Bansel 2010; Morrissey 2013; Rose 1990). Fourthly, there is a micropolitical approach that examines how power is contested at multiple levels and in dynamic, contradictory ways within the neoliberal university (Davies et al. 2005; Gillies and Lucey 2007). This set of discourses is often motivated by feminist understandings that conceive of power relationally and emphasise the localised work of ethico-political contestations that may be cultivated via personal interactions and professional duties, like $\mathrm{PhD}$ supervision or 'water cooler' conversations about the vicissitudes of academia (Gill 2009; Zabrodska et al. 2011).

Any one of these four sets of discourses would refract the issues addressed in the others. This paper takes the standpoint of the micropolitical approach. Micropolitical analyses of the university understand that neoliberalism is contested 'in here' as much as 'out there' (Peck 2003). Or as Stephen Ball (2012, 18) puts it, 'neoliberalism gets into our minds and our souls, into the ways in which we think about what we do, and into our social relations with others'. The Foucauldian analytic of governmentality is instructive here. Governmentality, which can be glossed as the government of self and others, or the conduct of conduct, offers a way to analyse the workings of power that is sensitive to Foucault's dual understanding of subjectivity; that is, subjectivity as being 'subject to someone else by control and dependence', and as the cultivation of 'identity by a conscience and self-knowledge' (Foucault 1982, 781). From the optic of governmentality, neoliberalism is not simply a political economic program that can be traced through the 'Chicago School' of economics to the political thought of Friedrich Hayek. Nor is it simply an ideological framework seeking to convince us of the veracity and/or inevitability of the neoliberal program. Rather, the second aspect of Foucault's understanding of subjectivity alerts us to the need also to be mindful of how neoliberal modes of governmentality act 
on relational capacities, how certain 'negative affects' are normalised such that the sustained and collective critique and refusal of neoliberalism is inhibited (Gilbert 2013, 15). From this perspective, what neoliberal hegemony thrives on is not consensus on its political economic program per se, but rather the acceptance of the pervasive experiences of insecurity, perpetual competition, and individual isolation as 'what life is really like'.

Critical discourses on the university all seek, with different emphasis, to expose the false inevitability of the neoliberal order of things. Regardless of the preferred approach, there is general consensus on the necessity for 'counterculture against neoliberalism' (Couldry 2012) and the need for collective awareness of the fact that 'resistance is not futile' (Callinicos 2006). For our purpose, I want to highlight micropolitical approaches that foster countercultural sensibilities by experimenting with different modes of address to cultivate those affective capacities and relations that are being inhibited. Consider, for instance, the work of Bronwyn Davies and her collaborators. In one of their studies where they interviewed academics about the impacts of corporatism on academia (Davies, Gottsche and Bansel 2006), it was noted that, despite the difficult and stressful conditions, the respondents still regarded academic work as a reward in itself. The interviewees agreed that ethical commitment to truth, free enquiry, collegiality, and public responsibility is crucial for intellectual life, and also said that the freedom to criticise received ideas or to disagree with the decisions of authority is important. But the responses of these interviewees (along with those in other studies) also indicate that academics have, to a large degree, taken up the entrepreneurial and managerial discourses of neoliberalism. 'Subjectivated' (cf Foucault) as free, autonomous, and responsible individuals, there was a marked tendency to 'disavow their own docility and see themselves as choosing to work in the ways they are working - as responsible for their own misery and for the inferior nature of their products' (Davies, Gottsche and Bansel 2006, 315). In another study, Davies and Bansel (2010) examine interview responses alongside public documents used during the Australian Universities Quality Assessment (AUQA) audit to show how the docile, 'responsibilised' moral subject of academia is produced through technologies of audit, performance, risk management and surveillance. They write:

[t]he self-interest of the academic is re-constituted in terms of the interest of the university, and the self-interest of the university translates back into the interest of the academic. These acts of translation install the interests of the institution at the heart of these transactions such that those who do not comply put the institution at risk. Conformity thus acquires a moral imperative larger than one's per- 
sonal survival as an ethical being (Davies and Bansel 2010, 9).

Leaving aside the specifics of the analyses performed by Davies et al., the arguments highlighted above should be sufficient to show that our passionate investment in the scholarly profession is being targeted as the object and objective of control. Therefore, along with the interrogation of the disciplinary apparatuses of the neoliberal university, it is important to also examine how we relate to these apparatuses and experience this environment - feelings of hope, disappointment, pride, shame, confidence, anxiety, and so forth about our capacity to honour the commitments and promises (or not) of the profession. Or at least, given the danger of political complicity or unacknowledged docility, it is important as a first step not to ignore or deny that there are non-rational (not to be confused with irrational) affective dimensions of academia that influence conscious intellectual activity and decisions. This is why I began with an anecdote about the imagined subjectivity of the resolutely rational and 'detached' academic and its regulatory function, which, if taken for granted, may hinder the taking of this first step towards the exposing of the depoliticising, injurious, and silencing effects of the neoliberal academic regime. Inasmuch as this first step requires us to articulate and share our feelings of vulnerability and uncertainty as well as our aspirations for hope and change - in short, a necessary turn or appeal to the other - the notion of 'faith' could be helpful as a guiding rubric for such micropolitical struggles.

SPEAKING PERSONALLY AND THE TRUTH-TELLING FUNCTION OF FINDING A VOICE

Consider, for instance, Gill's essay 'Breaking the silence: the hidden injuries of neo-liberal academia' (2009), which begins with a transcript of a conversation with a female academic friend. The conversation revealed that they are both feeling overworked and sleeping badly, and because it was impossible to take time off from administrative and teaching duties for 'reading' and 'thinking', both said they felt 'awful' (Gill 2009, 228-229). Her friend also revealed that the berating comments by a reviewer for a journal article submission had left her feeling like she was a 'complete fraud'. Gill $(2009,229)$ suggests that this fragment of conversation about 'exhaustion, stress, overload, insomnia, anxiety, shame, aggression, hurt, guilt and feelings of out-of-placeness, fraudulence and fear of exposure within the contemporary academy' would strike 'deep chords of recognition' with most readers. Indeed, these affective, embodied experiences are ordinary and everyday, as the respondents to the studies conducted by Davies et al. also reveal (Davies, Gottsche, and Bansel 2006; Davies and Bansel 2010). Yet, they remain largely secret and silenced in the public ex- 
changes of academia. As Gill notes, we typically speak about these experiences informally in the corridor or during coffee breaks but not in publications or at conferences or faculty meetings. So despite widespread interest in reflexive scholarship, ${ }^{1}$ it is as if the experiences of academics are somehow exempt from critical attention. Gill asks:

What would we find if, instead of studying others, we focussed our gaze upon our own community, and took as our data not the polished publication or the beautifully crafted talk, but the unending flow of communications and practices in which we are all embedded and enmeshed, often reluctantly [i.e. the various mechanisms of audit and feedback]. How might we make links between macroorganisation and institutional practices on the one hand, and experiences and affective states on the other, and open up an exploration of the ways in which these may be gendered, racialised and classed? How might we engage critically with the multiple moments in which individuals report being at breaking point, say 'my work is crap' or 'I'm going to be found out'... and connect these feelings with neoliberal practices of power in the Western University? In short, how might we begin to understand the secrets and silences within our own workplaces, and the different ways in which they matter? (Gill 2009, 229)

Importantly, this ought not be misconceived as an exercise in self-indulgence, nor is it about reifying a victimised self. For the 'I' who figures in this mode of address is articulated as the emergent and contested outcome of the mutualising dynamics between power relations, discursive regimes, and the ethical sensibilities that cohere between self and others and between the individual and institution. As a form of 'in-here' activism, it can be a way to plant seeds of change in the academic cultures within which we work, 'a crucial first step in making it possible (and even desirable) for academics to have fulfilling lives inside and outside the academy, and to engage in diverse forms of caring, support and activism' (Klocker and Drozdzewski 2012, 4). 'In-here' activism can be pursued via individual discourses like Gill's essay, which folds her own experience into the interrogation of the neoliberal academic regime. Or it can be pursued via group activity, like the experimental exercise of collective biography organised by Zabrodska, Linnell, Laws, and Davies (2011), which examines how bullying is implicated in the processes of subjectification within the neoliberal university. Their study shows that by articulating stories about bullying and then rewriting those stories in light of the encounter with the stories of others, the participants were able to better rewrite the self and recognise that their 
afflictive experiences of shame, humiliation, and failure are not symptoms of innate personal shortcomings, but are rather the normative effects of power generated by the disciplinary apparatuses circumscribing academic labour. In either case, 'in-here' activism entails the enunciative practice of 'speaking personally' and of 'finding a voice'.

Elspeth Probyn has explored the ethico-political implications of such an enunciative practice from the perspective of feminist-oriented cultural studies. She writes, 'I consider the possibilities of speaking selves to be great, and the liabilities of an untheorized return to the "I" to be even greater' (Probyn 1993, 11). The purpose of 'speaking personally' and the attendant process of working through the difficulties that one encounters, is a way to investigate the academic subject's own social embeddedness as a voice. Importantly, one engages in the work of 'finding a voice' with the understanding that "self-reflexivity" is not a licence for autobiographical writing but a theoretically informed examination of the conditions for emergence of "selves"' (Couldry 1996, 315). Building on Probyn's specific concern with gendered subjectivity, Couldry suggests that an enunciative practice of the self can be regarded as a mode of 'truth-telling' that is guided by 'a scepticism in speaking about others that is loyal to the uncertainties each analyst recognizes in the formulations of her or his own identity' (Couldry 1996, 315). To give an account of oneself whilst accepting that any account is already crossed many times over by others not 'my own', is 'to accept a sense of self that is necessarily suspended "in tension", internally inadequate and unstable' (Couldry 1996, 328). To persist in speaking the self in spite of irreducible complexity is implicitly to rely on a larger 'community' of other reflective agents. Or as Probyn $(1993,169)$ underscores, self-reflexivity should open a perspective which allows us to conceive of transforming ourselves with the help of others.' This is evinced by the studies surveyed above, where encounters with (the 'truth-telling' of) other selves opened up a space for critical reflection, allowing one to detach oneself from the processes of subjectification within the neoliberal university. The work of 'finding a voice' thus facilitates the cultivation of 'aspects of wider skills "for living", whose expression (and repression) stretch far beyond the academic sphere'; that is, 'long-term patterns of "resistance" which are barely recognizable as particular skills, but registrable at some point in a complete redirection of the narratives through which 'I' recognize myself against the definitions of others and against earlier selves' (Couldry 1996, 317).

Compare this mode of 'truth-telling' with that demanded by the technology of feedback in the neoliberal university. Whether it be feedback from the governmental audit processes circulated to management and staff or feedback from 
teaching evaluation surveys, 'feedback is situated as an unequivocal good, as providing naturally emerging truth accounts that reveal, for good or bad, the state of the university and the status of academic workers within it' (Davies and Bansel 2010,11). Through such circuits of feedback, staff members are enjoined to work with the university management to meet targets of 'quality', 'progress', 'entrepreneurship', and other markers of fundability. But as Davies and Bansel note, this 'collusion' rather than cooperation does not play out as a game of equals pragmatically responding to unavoidable government pressure: After all, such truth telling [between equals to interrogate the pressures stemming from the prevailing regime of power] might lead to collective resistance. Instead, technologies of audit are mobilised to generate the level of vulnerability that will guarantee the right performances, without resistance' $(2010,11)$.

In contrast, the 'truth-telling' performed by the vulnerable revelations of Gill's essay and the intersubjective narratives of bullying documented by Zadbroska et al. involve equals who are exploring countervailing responses to the neoliberal university. By speaking frankly about the anti-critical, depoliticising, and/ or injurious effects that are perpetuated but effaced by the positioning of technologies of audit as an unequivocal good, these enunciative practices reveal the equivocal feelings and attitudes that academic workers have towards normative expectations of scholarly 'quality' or 'professionalism. These accounts about the vicissitudes of academia are not articulated as naturally emerging truth accounts. Rather, they willingly foreground the irreducible complexity that circumscribes their 'truth-telling', revealing that their accounts of the academic self are necessarily dependent on the self-reflexive accounts of others for their truth value. Thus, it is not simply the objects of study in scholarly research (e.g. the activities of subcultural formations or institutions like the university) that are of heuristic and political value. Rather, the mode of address also holds critical, ethical, and political potentials. In this instance, the mode of address performs an act of witnessing. For inasmuch as the work of 'truth-telling' must necessarily presuppose a turn or appeal to the other, enunciative practices of 'speaking personally' and 'finding a voice' are constituted by a testimonial relation. Is any testimonial act or relation possible without the solicitation of trust, a profession of faith, of good faith?

\section{A PROFESSION OF FAITH IN THE UNIVERSITY WITHOUT CONDITION}

Derrida's thinking on the relation between religion and (techno)science can help us clarify this question and better locate the role of faith in academia. In 'Faith and Knowledge: The Two Sources of Religion and the Limits of Reason Alone' (2002), Derrida identifies two 'sources' of religion. One source is the 
promise of redemption, salvation, enlightenment, and so forth. The other is the testimonial act of promising that must be thought before the object of promise (salvation, etc.), since the act of promising recalls an originary turn towards or address of the other. Of the two sources of religion, Derrida claims that the latter is shared with (techno)science. This shared 'source' or condition of possibility is an elementary 'bare' faith, the promissory, quasi-transcendental condition of trustworthiness anterior to every speech-act, constative or performative (see also Naas 2012). Derrida also addresses the question of faith in The Gift of Death (1995), which engages with Kierkegaard's interpretation of Abraham's ir/ responsible sacrifice of Isaac to identify an understanding of faith that cannot be contained within Judeo-Christian identity. For Derrida, language represents the most general domain of faith (Derrida 1995), and he takes the view that there can be no sociality without an elementary faith or implicit promise of trustworthiness that enables every communicative relation with the other:

Each time I open my mouth, I am promising something. When I speak to you, I am telling you that I promise to tell you something, to tell you the truth. Even if I lie, the condition of my lie is that I promise to tell you the truth. So the promise is not just one speech act among others; every speech act is fundamentally a promise (quoted in Caputo 1997, 22-23).

More importantly for our purpose, I want to locate this understanding of faith in Derrida's lecture/essay, 'The Future of the Profession or the University Without Condition (thanks to the "Humanities," what could take place tomorrow)" $(2001),{ }^{2}$ where he insists on upholding the value of performative declarations that promise as they profess. Specifying that he is evoking a European model of the modern university, Derrida says that this 'university claims and ought to be granted in principle, besides what is called academic freedom, an unconditional freedom to question and to assert', as well as 'to say publicly all that is required by research, knowledge, and thought concerning the truth' (Derrida 2001, 24). The university without condition, or the unconditional university, has not yet come into existence, even though its received-but-unfulfilled promise inherits a legacy that can be traced through the Enlightenment to the theological tradition of scholasticism.

For Derrida (2001, 28-9), this ideal of the unconditional university has to be distinguished from 'all research institutions that are in the service of economic goals and interests of all sorts.' He does not examine the notion of the 'neoliberal university' as such, but he effectively situates his 'profession of faith' within this context when he says that the university today 'sometimes puts itself up 
for sale ... [and] risks becoming a branch office of conglomerates and corporations' (Derrida 2001, 28). What Derrida delineates instead are certain possible directions in which the 'new Humanities' could be cultivated for the university to come. The new Humanities must be capable of undertaking the task of deconstruction ad infinitum, beginning with the deconstruction of their own history and axioms. For example, this could involve the rethinking of their own history with regard to 'the act of professing' and 'the theology and the history of work, of knowledge and of faith in knowledge' (Derrida 2001, 49). ${ }^{3}$ Importantly, the purpose of pursuing the 'new Humanities' is not to contain them within the limits of traditional disciplines. Rather, Derrida $(2001,50)$ professes hope in the Humanities to come that will 'cross disciplinary borders without, all the same, dissolving the specificity of each discipline'.

In lieu of more thoroughgoing cross-disciplinary analyses of the lines of inquiry adumbrated by Derrida, my point here is simply to highlight the pertinence of a 'profession of faith' across the disciplines of the university - or at least, to pinpoint a micropolitics of a neoliberal university that is predicated on the truth-telling work of 'speaking personally'. Recalling the aforementioned understanding of faith as the quasi-transcendental, promissory condition of trustworthiness anterior to every speech-act - the elementary 'bare' faith presupposed and performed by every turn to or address of the other - Derrida says:

To profess is to make a pledge while committing one's responsibility. 'To make profession of' is to declare out loud what one is, what one believes, what one wants to be, while asking another to take one's word and believe this declaration.... The discourse of profession is always, in one way or another, a free profession of faith; in its pledge of responsibility, it exceeds pure techno-scientific knowledge. To profess is to pledge oneself while declaring oneself, while giving oneself out to be, while promising this or that $(2001,36)$.

To profess as a (would be) professor of the university, it is 'neither necessarily to be this or that nor even to be a competent expert; it is to promise to be, to pledge oneself to be that on one's word .... [and] to devote oneself publicly, to give oneself over to .... [the declarative commitment], to bear witness, or even to fight for it' (Derrida 2001,36). More importantly, 'what matters here is this promise, this pledge of responsibility, which is reducible to neither theory nor practice' (Derrida 2001, 36). The discourses articulated by Gill and the collective biographical narratives documented by Zabrodska et al. are arguably performing such a profession of faith that pledges as it promises. They 
may not have explicitly formulated their discourses in these terms but their undertaking of an enunciative practice of the self is prompted by a conviction that the critico-political value of scholarly work (rather than its monetary or entrepreneurial 'branding' value) is worth fighting for. Their discourses are not primarily concerned with claiming expertise - in fact, they openly admit the uncertainty and incompleteness of knowledge - but are rather giving witness to other academic workers who likewise grapple with the normative operations of the neoliberal university. Their 'truth-telling' is a testimonial act and declarative pledge of commitment to the public duty of the scholarly profession, an affirmation of what is worth fighting for in the university, a struggle for a different university to come.

For Derrida, the ethico-political force of declarative pledges of commitments consists in their performativity. The deconstructive understanding of 'performativity', which builds on Austin's speech-act theory and which Judith Butler (1997) has employed in her work, is very different to the moral system and disciplinary technology of performativity instituted within the neoliberal university. The latter links effort, values, purposes, and self-understanding to comparative measures of output in order to produce the docile, compliant academic subject. For Derrida, by contrast, the force of the performative derives from 'its decontextualization, from its break with a prior context and its capacity to assume new context', and thus offers a means 'to break with prior contexts, with the possibility of inaugurating contexts yet to come' (Butler 1997, 147, 152). The university without condition is one such possible context yet to come, a praxis-ideal for an affirmative, future-oriented or futural politics. Derrida's deconstructive treatment of the notion of the messianic is instructive here to further elucidate the role of faith in a futural struggle for a different university. The messianic is one of many iterations of différance and a way to think the fundamental deconstructive insight - that nothing is simply present to itself in relation to temporality. The messianic bears witness to the incoming of time, which arrives at once as the condition of possibility and impossibility for the movement of life, since it also recalls and announces finitude, the absence or utter contingency that haunts every 'now'. Also described as 'messianicity without messianism', it refers to 'the opening to the future or to the coming of the other as the advent of justice, but without horizon of expectation and without prophetic prefiguration .... At issue there is "a general structure of experience" that is suffused with faith (Derrida 2002, 56).

John D. Caputo (2001) reads in Derrida's claims a 'religious sense of life' or a notion of 'religion without religion' demanding nothing less than faith, love, and hope. Perhaps it is meant as a provocation against secularist hubris, but by 
'the religious' Caputo does not refer exclusively to organised religion. Rather, as per Derrida's rendering of messianicity, 'the religious' constitutes 'a basic structure of our lives ... that should be placed alongside very basic things, like having an artistic sense or political sense' (Caputo 2001, 8-9). Martin Hägglund (2008), however, opposes such theologically-inspired readings with the counterclaim that deconstruction professes a 'radical atheism'. Resolutely committed to a non-religious stance of immanence, radical atheism is nevertheless gracious in accepting the call of and for faith as it affirms the time of life: 'We can never know for sure what will happen because experience is predicated on the unpredictable coming of time. Whatever we do, we place faith in a future that may shatter our hopes and lay to waste what we desire' (Hägglund 2008, 126).

If every speech-act is fundamentally a promise, a solicitation of trust - and if enunciative practices of the self must necessarily make an appeal to the other and are thus constituted by a testimonial relation - the understanding of faith I am proposing is pertinent to 'believers' and 'nonbelievers' alike, regardless of whether one tends towards theistic or atheistic commitments or otherwise. The movement of temporality, the possible interruption of every 'now' by an incalculable future to come, implies that we are always and already given over to and held by faith - or 'good faith', at any rate. It is as if the struggle against the current neoliberal academic regime, as if every decision to 'speak personally' in order to expose the violence of prevailing practices, is signed off with 'Yours faithfully'. My proposal is that greater sensitivity towards this openended movement of faith that is irreducible to any ontotheological proposition could help us to become more sensitive to the role of scholarly affect and foster sympathetic relations of reciprocity and solidarity within and against the neoliberal academic regime.

\section{SCHOLARLY AFFECT AND GOOD FAITH}

The idea of scholarly affect is drawn from Melissa Gregg's Cultural Studies Affective Voices (2006), which participates in the broader critical turn in humanities and social science scholarship towards the affective dimensions of everyday life and political activity (Clough and Halley 2007; Seigworth and Gregg 2010). ${ }^{4}$ Gregg's work proceeds on the understanding that academia is a passionate vocation suffused with visceral experiences:

the hopeful trajectories a writer's voice can encourage as you read their work, the stimulus and provocation of peers, the confidence a mentor can inspire in a student are just some of the energies which help sustain what would otherwise seem a solitary vocation. Think 
too of the fear and adrenaline that come with presenting work in public, the ferocity with which disciplinary ideologues stake out their turf, the indignant soliloquies of aging colleagues faced with one more bureaucratic imposition or the consuming doubt that can descend on even the most gifted writers. The immense range of affective scenarios in academia is formidable $(2006,6-7)$.

The affectivity of these visceral experiences exceeds conscious knowing but necessarily animates the work of knowledge production. As we have seen, the affectivity of such relational encounters in academia provides a conduit for the exercise of power, whether it be the exercise of power via formal processes of audit, feedback, risk management, or informal encounters of bullying. Echoing Gill's point above about the silences of academia, Gregg seeks to redress the tendency in academia to downplay these rich and vital dimensions of scholarly life. Paying attention to the affective nature of scholarly practice, she argues, is a way to signal 'the importance of collegiality and community in assisting the difficult choice which is to make a living from thinking seriously and differently' (Gregg 2006, 7). For those of us who are still invested in the university as the appropriate location for the kind of interdisciplinary and other-oriented interventions that have been performed under the rubric of cultural studies, the challenge is 'to communicate the continued worth of scholarly life despite the difficulties of present conditions' (Gregg 2006, 25). One way to meet this challenge is to take 'seriously the idea that writing in the humanities can be affirmative or inventive' (Massumi 2002,17). Such a move may help to strengthen the capacity to resist 'the dominant mode of investment at work in scholarly practice' (Gregg 2006, 19), and thereby to remake and reinvest in the university anew.

Existing critical discourses on the neoliberal university are already pursuing this objective of revitalising the scholarly profession. For example, in examining the governmentality of the neoliberal university, Davies, Gottsche, and Bansel argue that by becoming aware of 'the conditions through which [the rise of neoliberalism in universities] has been discursively and materially installed as inevitable and necessary', we are also beginning 'to imagine and mobilise strategic action towards acts which in turn forestall the appropriation of our work and our lives by neo-liberal ideals' $(2006,318)$. Just as the rise of neoliberalism cannot be traced to any linear and massively orchestrated events, its fall or disruption would have to emerge from small, local and co-extensive critiques. In his analysis of the impacts of commodification and technologies of performativity on scholarly commitment, Ball $(2012,26)$ expresses a similar ethico-political sentiment: 'While we need to understand how these elements 
[of the neoliberal regime] and their relations enter into us and encourage us to work on ourselves in a variety of ways, we also need to hold firmly onto a sense that we are none of the things we now do, think or desire.'

These are emphatic pleas - calls to arms - for countercultural activism against the neoliberal academic regime. Although they do not use such terms as 'affective investment' or 'profession of faith', I think we can profitably read them through Gregg's proposals about scholarly affect and Derrida's thoughts on the university without condition. To paraphrase the above, enunciative practices that 'speak personally' and engage in 'truth-telling' about the vicissitudes of academia, are imagining and mobilising strategic action towards acts which in turn forestall the appropriation of our work and our lives by neoliberal ideals. Such strategic action, as I have suggested, is predicated on witnessing, on the cultivation of testimonial relations with others. Writings that foreground the ways in which the affective, relational, and/or politically-galvanising capacities of scholarly practice are being exploited or inhibited by the prevailing neoliberal regime, can serve to help us hold firmly onto a sense that we are none of the things we now do, think, or desire. They are, in other words, a means to reinvest in the scholarly profession, a different mode of investment in the university that is not narrowly fixated with the bottom line of research- and teaching-as-business. These micropolitical struggles to 'reinvest' in a different university to come, turn on the recognition that the scholarly profession is suffused with visceral experiences, that our passion for the profession (of faith?) is being targeted as the object and objective of control by the apparatuses of the neoliberal academic regime. As Brett Neilson and Angela Mitropoulos (2005, n.p.) write, 'an excess of passion has served as an ostensibly non-coercive means to bind academic labourer to the university system', but 'there is no necessity which decrees that it cannot be otherwise, facilitating an exodus, a demand for another university, here and now?

This point about scholarly passion relates back to Hills's observation quoted at the start of the paper: 'the possibility that faith is the ultimate glue within academic argument is typically disavowed and ignored in favour of the imagined subjectivity of the rational academic' $(2002,3-4)$. In view of the foregoing discussion, we could perhaps say that faith is the 'ultimate glue' in the deconstructive sense: at the heart of every speech-act is a promise, an elementary 'bare' faith or quasi-transcendental condition of trustworthiness, which makes possible every communicative relation and social bond. But faith is also the 'ultimate glue' in another sense: our affective investment of trust or conviction that what we do can and will make a difference - our passionate commitment to truth, free enquiry, collegiality, and public responsibility - is what gives the 
profession vitality as a socially-engaged livelihood. But our abiding faith in the virtues of the scholarly profession and its critico-political function is being exploited and inhibited by the disciplinary apparatuses of the neoliberal university. Hence, my proposal that enunciative practices that 'speak personally' as well as 'truth-telling' about the depoliticising, injurious, and silencing effects of prevailing disciplinary apparatuses, could play a role to help us unbind ourselves from the seemingly non-coercive, normative power of the neoliberal academic regime. This is a form of 'in-here' activism to re-bind ourselves in solidarity, a means to reinvest in the scholarly profession anew, a micropolitical struggle to welcome a different university, a university without condition.

\section{CONCLUSION}

This paper has argued for the importance of 'in-here' activism via micropolitical struggles over the hopes and aspirations, duties and commitments of the scholarly profession. It principally inhabits the scholarly mode of academic work which, according to Ruth Barcan (2013), exists alongside two other operational modalities within the neoliberal university: the bureaucratic and the corporate modes. For Barcan, the conundrums and contradictions of the neoliberal university can be fruitfully unpacked by tracing the tensions that cohere within and across these three modalities: the 'higher calling' of the scholarly profession, the organisational norms of bureaucratic rationality, and the entrepreneurial ethos of the corporate 'brand'. Each places specific demands on the academic labourer, but they also exert cross-pressures to variously enhance, exploit, or displace the operational logics of one another. ${ }^{5}$ My proposal about the role of faith in academia is a response to the fact that there is a particularly effective - or rather, exploitative - synergy between the scholarly and corporate modes. Both solicit the immaterial affective labour and investment of the academic towards a 'higher calling': on the one hand, the scholarly mode solicits faith in the 'common good' for which the criticality of the profession is believed to provide, and on the other, the corporate mode solicits faith in the entrepreneurship of 'the brand' for which the profitability of the profession is believed to provide. The question of faith formulated in this paper can thus be summarised as: how do we tease apart the ways in which our passionate investment in the public duty of the profession is being exploited or subsumed by the privatising pursuit of the corporate brand, which likewise solicits from us passionate investment? The investigation of this question has to be a collective task, and my proposal is that we explore ways to take the necessary first step of acknowledging that ours is, in all senses of the word, a profession of faith.

One way to take this first step is to experiment with our modes of address 
by communicating 'personally' and affirmatively - by enacting testimonial relations of intellectual hospitality and good faith - in scholarly exchanges. This paper has admittedly been very cautious with its experimentations. The obvious reason for this is because I have to devote space to contextualising and explaining the rationale for my arguments. But part of the reason, I must also admit, is because I was worried that an unconventional presentation style may not be received favourably by the editors and especially the anonymous reviewers-not to mention that the topic of faith could potentially provoke hostile or dismissive reactions within an academic regime of truth governed by narrowly conceived secularist norms, as the anecdote I shared at the start of this paper suggests. But the responses from the editors of this special issue and the two anonymous reviewers have been overwhelmingly supportive and encouraging. So I want to take this opportunity to briefly reflect on their feedback as a means to close this paper with an affirmative, testimonial mode of address.

One of the reviewers was very generous in offering pointers on how I can further develop the philosophical nuances of my Derridean-inspired conceptualisation of faith. This reviewer also asked that I reflect on unacknowledged privilege in the politics of scholarly faith, so as to better elucidate how collective acknowledgment and inquiry of our profession of faith might add to or change the prevailing order of things. ${ }^{6}$ More specifically, the reviewer invited me to ponder on the hypothetical scenario whereby the neoliberal university might allow me to publicly profess a dissident faith, and even to carve a successful career by professing an alternative faith from within and against the system, without necessarily disrupting prevailing arrangements as such. I have incorporated this reviewer's suggestions by discussing the three operational modalities of the neoliberal university, noting in particular how collective acknowledgment and inquiry of our profession of faith might help us to unpack the cross-pressures between the scholarly and corporatist modes. But even though the scenario of political complicity depicted by the reviewer bespeaks a valid concern, I have to honestly say that I do not know how to address it because the fact is I am not in that position of privilege and I do not have adequate experience to speculate on such career prospects in an informed manner. Being a recent $\mathrm{PhD}$ graduate and a casually employed academic of nine years, I am working precariously at the periphery of the neoliberal university and living with significant anxiety as a 'para-academic' (Wardrop and Withers 2014). Not only do I not have the luxury and security of full-time employment by which I may build a career by professing a dissident faith 'from within', I have also reasons to suspect that one of my attempts to publicly state the scholarly function of a non-doctrine-specific understanding of faith was subject to an act of censorship by an institution with which I am affiliated. ${ }^{7}$ 
So my experience as a para-academic is quite different to the hypothetical scenario raised by the reviewer. If anything, my experience suggests that it may not be all that easy to cash in on a dissident faith from within the current culture of audit and compliance. And I am not alone in facing this climate of precarity. In a heavily casualised higher education sector there are many, many para-academics who are grappling not only with the challenge of securing a livelihood but also a crisis of faith in the viability of the profession-a seemingly immaterial matter of hope and trust in the future that is mutually conditioned by material relations of production and belonging. There is an injurious silence at the heart of the neoliberal university. My hope is that this paper would at least pique curiosity about how paying collective attention to the faithful pulsating heart of academia might foster sympathetic relations of reciprocity and solidarity amongst para-academics and between para-academics and tenured academics.

I articulate these reflections also as a response to the second reviewer who suggested that I end the paper with a 'faith-filled note' of what could be done differently. It is not customary to explicitly foreground the editors' and anonymous reviewers' suggestions within the body of the text, although it is customary to acknowledge them in the periphery, usually in a note. But in thinking through the reviewers' and the editors' feedback to this profession of faith - more precisely, in feeling surprised and encouraged by how receptive and supportive they are to what I had feared would be a discomfiting proposal - it occurred to me that this inherited practice of blind peer-reviewed publishing, a practice which remains highly regarded within the scholarly profession (albeit in increasingly calculative ways by the bureaucratic and corporate agendas of the university), is constituted by a testimonial relation. Can there be any testimonial relation without good faith? Such a reciprocal gifting of faith-astrust usually operates implicitly within academic publishing. We submit the fruits of our labour to the invisible scrutinising gaze of anonymous others who, we can only hope, would receive our work with intellectual hospitality and good faith. But there is no guarantee of reciprocity, as illustrated by Gill's story above about a friend who was left feeling like a 'complete fraud' after receiving berating comments from a reviewer. That there is no guarantee, that we cannot know in advance, is precisely why the movement of faith always already supports our pursuit of knowledge. Inasmuch as a testimonial relation already constitutes our scholarly practice, how might we collectively acknowledge, inquire into, and harness the countercultural potentials of this affective force that is already at work in the making of our profession? My feeling is that the countercultural potential of this task lies in the revitalisation of the collegiate. I thank the editors and the anonymous reviewers for extending intellectual 
hospitality and good faith towards this paper, which I submit as a modest proposal to invite conversations to come about the role of faith in academia: our profession of faith.

Yours faithfully

Edwin $\mathrm{Ng}$

NOTES

1 This is exemplified by the genre of autoethnography in qualitative research (see Ellis, Adams, and Bochner 2011).

2 I have not previously capitalised 'humanities', but to refer specifically to Derrida's ideas I will render it as 'Humanities'.

3 I state only these as they are most pertinent to the present discussion, but Derrida $(2001,49)$ also mentions 'the question of man, of the world, of fiction, of the performative and the "as if," of literature and of oeuvre'. See Miller (2005) for a discussion of Derrida's claims about literature and its relation to the profession of the unconditional university, sovereignty, and democracy.

4 It is beyond the scope of this paper to delineate the specific focus of the different strands of scholarship that have pursued the so-called 'affective turn'. The reader is directed to these resources for an overview. But summarily speaking, to think affectively is to adopt the understanding that there are visceral forces at work that fall under the radar, as it were, of conscious knowing. The affective potentials of these forces are the target of power, but by the same token, they can be harnessed to actualise different patterns of thought, action, and relations.

5 See Barcan's book (2013) for a detailed treatment of how these three operational modalities of the neoliberal university function through their corresponding ideal types (the scholar/professor, the bureaucrat/manager, and the corporatist/ entrepreneur) to circumscribe academic life and labour today.

6 The reviewer speaks of privilege in two senses: that academics are relatively privileged as compared to other neoliberal employees in society, and that the cultural cachet associated with freedom of enquiry/expression in the scholarly profession affords a degree of privilege (I address this in the remainder of the paragraph). With regard to the relative privilege that academics might hold over others, we might note here that in arguing for greater critical reflexivity about the immaterial labour of affect in academia, Gregg (2010) proposes that it could 
be one way by which academic workers begin to recognise and act on their shared conditions with other neoliberal employees outside the university.

7 Because of the risk it presents to the already minimal and precarious institutional support I am dependent on, I am not at liberty to elaborate on the details.

\section{BIBLIOGRAPHY}

Ball, S. 2012. 'Performativity, commodification and commitment: an I-spy guide to the neoliberal university'. British Journal of Educational Studies 6o(1): 17-28.

Banks, M. 2007. The Politics of Cultural Work. Basingstoke New York: Palgrave Macmillan.

Barcan, R. 2013. Academic Life and Labour in the New University: Hope and Other Choices, Farnham: Ashgate.

Bauman, Z. 200o. Liquid Modernity. Cambridge: Polity Press.

Beck, U. 200o. The Brave New World of Work. Cambridge: Polity Press.

Butler, J. 1997. Excitable Speech: A Politics of the Performative. New York: Routledge.

Callinicos, A. 2006. Universities in a Neoliberal World. London: Bookmarks Publication.

Canaan, J., and W. Shumar, eds. 2008. Structure and Agency in the Neoliberal University. New York: Routledge.

Caputo, J.D., ed. 1997. Deconstruction in a nutshell: a conversation with Jacques Derrida. New York: Fordham University Press.

Caputo, J.D. 2001. On Religion. London and New York: Routledge.

Clough, P., and J. Halley, eds. 2007. The Affective Turn. Durham: Duke University Press.

Couldry, N. 1996. 'Speaking about others and speaking personally.' Cultural Studies (10) 2: 315-33.

- 2012. 'Universities and the necessary counter-culture against neoliberalism.' 
IC: Revista Científica de Información y Comunicación 9: 61-71.

Crang, M. 2007. 'Flexible and fixed times working in the academy'. Environment and Planning A 39: 509-514.

Davies, B., and P. Bansel. 2010. 'Governmentality and academic work: shaping the hearts and minds of academic workers.' Journal of Curriculum Theorizing 26(3): 5-20.

Davies, B., J. Browne, S. Gannon, E. Honan, and M. Somerville. 2005. 'Embodied women at work in neoliberal times and places.' Gender, Work and Organization 12: 343-362.

Davies, B., M. Gottsche, and P. Bansel. 2006. 'The rise and fall of the neo-liberal university.' European Journal of Education 41(2): 307-319.

Derrida, J. 1995. The Gift of Death. Translated by D Wills. Chicago: University of Chicago Press.

- 2001. 'The future of the profession or the university without condition (thanks to the "Humanities" what could take place tomorrow).' In Jacques Derrida and the Humanities: A Critical Reader, edited by T. Cohen, 24-57. Cambridge: Cambridge University Press.

- 2002. 'Faith and knowledge: the two sources of "religion" at the limits of reason alone.' In Acts of Religion, edited by G. Anidjar. 40-101. London; New York: Routledge.

Dowling, R. 2008. 'Geographies of identity: labouring in the "neoliberal” university.' Progress in Human Geography 32: 812-820.

Ellis, C., T. Adams and A. Bochner. 2011. 'Autoethnography: An Overview.' Forum: Qualitative Social Research 12(1). Accessed 28 April 2014, http://www. qualitative-research.net/index.php/fqs/article/view/1589/3095.

Evans, M. 2005. Killing Thinking: The Death of the University. London: Continuum.

Foucault, M. 1982. 'The subject and power.' Critical Inquiry 8(4): 777-795.

Gibson, C. 2007. 'Geography in higher education in Australia.' Journal of Geography in Higher Education 31: 97-119. 
Gilbert, J. 2013. 'What kind of thing is "neoliberalism"' New Formations: A Journal of Culture/Theory/Politics 80-81: 7-22.

Gill, R. 2009. 'Breaking the silence: the hidden injuries of the neoliberal university' In Secrecy and Silence in the Research Process: Feminist Reflections, edited by R. Flood and R. Gill, 228-244. London; New York: Routledge.

Gill, R. and A. Pratt. 2008. 'In the social factory? Immaterial labour, precariousness and cultural work.' Theory, Culture \& Society 25(7-8): 1-30.

Gillies, V. and H. Lucey, eds. 2007. Power, Knowledge and the Academy: The Institutional is Political. Basingstoke; New York: Palgrave McMillan.

Graham, G. 2002. Universities: The Recovery of an Idea. Exeter: Imprint Academic.

Gregg, M. 2006. Cultural Studies' Affective Voices. New York: Palgrave McMillan.

- 2010. 'Working with affect in the corporate university.' In Working with Affect in Feminist Readings: Disturbing Differences, edited by M. Liljeström and S. Paasonen,182-192. London; New York: Routledge.

Hägglund, M. 2008. Radical Atheism: Derrida and the Time of Life. London; Stanford, California: Stanford University Press.

Hardt, M. and A. Negri. 20oo. Empire. Cambridge, MA: Harvard University Press.

Hill, D. and R. Kumar. 2009. Global Neoliberalism and Education and Its Consequences. New York: Routledge.

Hills, M. 2002. Fan Cultures. London; New York: Routledge.

Klocker, N. and D. Drozdzewski. 2012. 'Survival and subversion in the neoliberal university’. University of Wollongong Research Online. Accessed 28 February, http://ro.uow.edu.au/smhpapers/1184/.

Massumi, B. 2002. Parables for The Virtual. Durham; London: Duke University Press.

McDowell, L. 2004. 'Work, workfare, work/life balance and an ethic of care.' Progress in Human Geography 28: 145-163. 
McRobbie, A. 2003. 'Club to company'. Cultural Studies 16(4): 516-531.

McKinnon, A. 2006. 'Opium as dialectic of religion: metaphor, expression, and protest.' In Marx, Critical Theory and Religion, edited by W. Goldstein. 11-30. Boston: Brill.

Morrissey, J. 2013. 'Regimes of performance: practices of the normalised self in the neoliberal university. British Journal of Sociology of Education 34: 1-24.

Miller, J.H. 2005. 'Sovereignty, death, literature, unconditionality, democracy, university.' In Deconstructing Derrida: Tasks for the New Humanities, edited by M.A. Peters and P.P. Trifonas. 25-36. New York: Palgrave McMillan.

Naas, M. 2012. Miracle and Machine: Jacques Derrida and The Two Sources of Religion, Science, and the Media. New York: Fordham University Press.

Neilson, B. and A. Mitropoulos. 2005. 'Polemos, Universitas.' Borderlands 4(1). Accessed 15 March 2014. http://www.borderlandsejournal.adelaide.edu.au/ vol4no1_2005/neilsonmitropoulos_polemos.htm.

Ng, E. 2012a. 'The autoethnographic genre and Buddhist studies: reflections of a postcolonial “Western Buddhist” convert.' Australian Religion Studies Review 25(2): 163-184.

- 2012b. 'Buddhism, poststructuralist thought, cultural studies: a profession of faith.' Cultural Studies Review 18(2): 109-128.

Probyn, E. 1993. Sexing the Self: Gendered Positions in Cultural Studies. London; New York: Routledge.

Peck, J. 2003. 'Geography and public policy: mapping the penal state.' Progress in Human Geography 27(2): 222-232.

Roberts, C.J. 2005. 'On secularization, rationalization, and other mystical things: the unfinished work of Marx's religious criticism.' Iowa Journal of Cultural Studies 7. Accessed 28 October 2013. http://www.uiowa.edu/ ijcs/secular/ roberts.htm.

Rose, N. 1990. Governing the Soul: The Shaping of the Private Self. London; New York: Routledge. 
Ross, A. 2003. No Collar: The Humane Workplace and its Hidden Costs. New York: Basic Books.

Seigworth, G.J. and M. Gregg. 2010 (eds), The Affect Theory Reader. Durham: Duke University Press.

Sennett, R. 2006. The Culture of the New Capitalism. New Haven: Yale University Press.

Smith, B.H. 1988. Contingencies of Value: Alternative Perspectives for Critical Theory. Cambridge, Mass.: Harvard University Press.

Wardrop, A. and D. Withers. 2014. The Para-Academic Handbook: A Toolkit for Making-Learning-Creating-Acting. London: HammerOn Press.

Washburn, J. 2003. University, Inc.: The Corporate Corruption of Higher Education. New York: Basic Books.

Zabrodska, K., S. Linnell, C. Laws, and B. Davies. 2011. 'Bullying as intra-active process in neoliberal universities.' Qualitative Inquiry 17(8): 709-19. 